\title{
Increase in Litter Size and Decrease of Post-implantation Loss of Fetuses Observed in an SPF Colony of Wistar-Imamichi Rats
}

\author{
Yasumasa WAKAFUJI, Ryouji HOKAO, Hiromi AMAO, Kazuaki W. \\ TAKAHASHI* and Tomonori IMAMICHI* \\ Imamichi Institute for Animal Reproduction, Dejima-mura, Niiharigun, \\ Ibaraki 300-01 Japan and *Nippon Veterinary and Zootechnical \\ College, Musashino-Shi, Tokyo 180
}

(Received 21 June 1983/Accepted 21 December 1983)

\begin{abstract}
The number of delivered offspring, corpora lutea and implantation sites was observed in an SPF colony of Wistar-Imamichi rats bred in a barrier system free of specified microorganisms and parasites and was compared with that of rats bred under conventional conditions. The litter size of 6142 SPF rats ranged from 1 to 20 , averaging $12.4 \pm 0.04$, a value significantly higher $(P<0.001)$ than that of conventionally bred rats $(11.0 \pm 0.04)$. Although the number of corpora lutea was also higher in SPF rats than under conventional conditions, the number of post-implantation losses in SPF rats with less than 10 offspring showed a marked decrease compared with conventionally bred rats. These results show that the number of delivered offspring is higher in SPF rats than in conventionally bred rats and indicate that the increase in litter size is due to the increase in the number of corpora lutea and decrease in postimplantation loss of embryos or fetuses.
\end{abstract}

\section{Wistar-Imamichi Rat の SPF 化に伴う産仔数の}

増加と还・胎仔の損失減少について

若藤靖匡・外尾亮治・天尾弘実

高橋和明*.今道友則*

財団法人動物繁殖研究所

$*$ 日本獣医畜産大学

著者らは多産系ラットとして育種改良されたWistarImamichi Rat [1] の中より，少数ではあるが認めら れる低産仔数発現の主要因, 拉よび産仔数を向上させた 育種成果の成因について詳細に検討している。これまで にコンベンショナルな飼育条件下での低産仔数発現要因 として, 初産ラットでは受精卵の着床損失と胚・胎仔の
着床後の損失が見られること[10], さらに初産で低産仔 数の母親は 2 産に批いても産仔数が少なく，その原因は 初産と同様に着床前後の損失によるものであること等を 報告した[11]。しかし産仔数のような量的形質は環境の

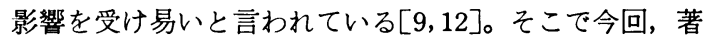
者らは環境条件を整えた（温度, 湿度, 風量, 照明の調 
節のみならず病原微生物や寄生虫の侵入を可能なかぎり 防御した）厳重な隔離方式施設 (Barrier System) で 飼育した動物を用い，産仔数と妊娠黄体数および着床痕 数を観察して着床前後の胚・胎仔の損失率について検討 した。さらにこれらの成績を既報 [10] のコンベンショ ナル条件下 (conv. ラット) での成績とも比較検討した ので報告する。

\section{材料およひ方法}

供試動物：生後 $10 \sim 13$ 週龄で 繁殖に供用した SPF Wistar-Imamichi Rat の初産 6,142 匹と同週龄の処 女35匹を供試した。

生産方法：当研究所に捕けるWistar-Imamichi Rat の種親選抜基準で選び出した種親をクローズドコロニー 維持方式にしたがい，雄 1 対雃 5 を 2 週間同居交配させ た。

飼育環境：Barrier System による飼育条件下で, 温 度 $24 \pm 1^{\circ} \mathrm{C}$, 湿度 $50 \sim 60 \%$, 換気回数 1 時間に約 13 回 ( $5 \mu$ フィルターで滤過した清浄空気)，人工照明14時間 （午前 5 時〜午後 7 時）に設定した動物室で飼育した。 飼料は標染配合飼料 (小麦, トウモロコシ, 魚粉, 大豆 粕をそれぞれ $6: 3 ： 1 ： 1$ の割合で混合）打よび固型 飼料 $\mathrm{MM}-2$ (船橋農場) を高圧蒸気減菌器により $120^{\circ} \mathrm{C}$ 20 分間消毒し標準配合飼料 20 に対し固型飼料 1 の割合で 加えて給与し, 飲水は 60 分間蒸気滅菌をして給与し, 自 由に摄取させた。飼育者は専用入口シャワー室で楽用石 鹼を用いて全身を洗い流し, 減菌された作業衣, 帽子, マスク，手袋，靴を着用して飼育室の作業に従事した。

分婏の観察と産仔数の調查 : 妊娠動物 6,142 腹の分婏 は毎日午後 $3 \sim 5$ 時に観察し, 前日観察後から当日観察 時までに分婏した母数および産仔数を記録した。

解剖検査：初産動物6,142腹のうち228腹を分婏の翌日 正午に解剖した。剖検に際して卵巣と卵管をすみやかに 取り出し，卵管については生理食塩液を 1 滴置いたスラ イドグラスの上に置き，その上に他のスライドグラスを 乗せて 2 枚のスライドグラスの間に挾み約30～60分間放 置した後，位相差顕微鏡下で観察して排卵数を調べた。 卵巣については解剖顕微鏡下で観察し, 直径 $1 \mathrm{~mm}$ 以上 の大きく成長している黄体のみを妊娠黄体数として数え た。子宮については切開し, 着床痕数を調べた。なお妊 娠時の排卯数は直接観察ができないために同週龄の 4 日 周期処女35匹を発情期の日に解剖して排卵数を調へ，妊 娠時の排卯数の推定の補助にした。また参考までに卵巣
および子宮の臟器重量を測定した。

統計処理: Duncan' new multiple-range test と Student $の \mathrm{t}$ 検定法打よび二元配置の 分散分析法をも ちいて測定値の有意差を検定した。

病原体検査：供試動物の中からランダムに抽出された SPF ラット 20 匹扰よび conv. ラット19匹について, 病原体扰よび血清の検查を国立予防衛生研究所に依頼し 感染病の有無を調べた。

\section{成}

1）初産の SPF ラットに打ける産仔数の分布：実験期 間中における SPF 飼育室全体の初産ラット 6,142 腹に ついて産仔数の分布を Fig. 1 に示す。破線で示したカ ラムは既に報告した conv. ラット（6,215腹）に打ける 成績 [10] である。SPF ラットの産仔数は 1～20匹に分 布し，その平均土標準誤差は12.4 00.04 であった。各産仔 数を分婏した母動物の割合は13〜14匹群 $(1,861 / 6,142$, 30.3\%）を頂点とする一峰性の分布を示し，19２0匹群 (49/6, 142，0.8\%) が最も低值を示した。そして $1 〜 2$ 匹群 $(71 / 6,142,1.2 \%)$ や $3 \sim 4$ 匹群 $(137 / 6,142$,

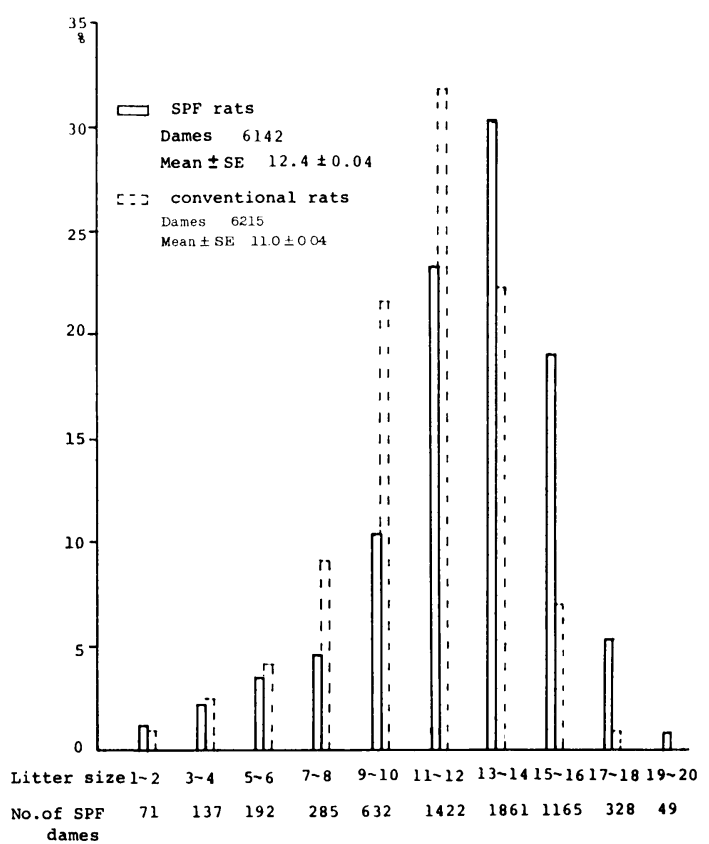

Fig. 1. Frequency distribution of litter size in primiparous SPF and conventional[10] Wistar-Imamichi rats. 
Table 1. Litter size, implantation sites, corpora lutea of pregnancy and post-partum ova of primiparous SPF Wistar-Imamichi rats

\begin{tabular}{|c|c|c|c|c|c|c|c|}
\hline $\begin{array}{l}\text { Class } \\
\text { of litter } \\
\text { size }\end{array}$ & $\begin{array}{l}\text { No. of } \\
\text { dams }\end{array}$ & $\begin{array}{l}\text { Average } \\
\text { litter size }\end{array}$ & $\begin{array}{l}\text { Pre-implan- } \\
\text { tation loss }\end{array}$ & $\begin{array}{l}\text { Post-implan- } \\
\text { tation loss }\end{array}$ & $\begin{array}{l}\text { No. of } \\
\text { implantation } \\
\text { sites }\end{array}$ & $\begin{array}{l}\text { No. of } \\
\text { corpora } \\
\text { lutea }\end{array}$ & $\begin{array}{l}\text { No. of ova of } \\
\text { post-partum } \\
\text { ovulation }\end{array}$ \\
\hline $1-2$ & 13 & $1.5 \pm 0.1^{*}$ & $13.2 \pm 1.0 \mathrm{a}$ & $1.2 \pm 0.4 \mathrm{e}$ & $2.7 \pm 0.5 \mathrm{~g}$ & $15.8 \pm 0.9 \mathrm{n}$ & $17.8 \pm 0.9 q$ \\
\hline $3-4$ & 25 & $3.4 \pm 0.1$ & $11.4 \pm 0.7 \mathrm{a}$ & $1.1 \pm 0.4 \mathrm{f}$ & $4.4 \pm 0.5 \mathrm{~h}$ & $15.8 \pm 0.5 \mathrm{n}$ & $18.0 \pm 0.5 \mathrm{q}$ \\
\hline $5-6$ & 28 & $5.5 \pm 0.1$ & $7.6 \pm 0.7 \mathrm{~b}$ & $2.4 \pm 0.6 \mathrm{e}$ & $7.9 \pm 0.6 \mathrm{i}$ & $15.5 \pm 0.5 \mathrm{n}$ & $18.4 \pm 0.5 \mathrm{q}$ \\
\hline $7-8$ & 30 & $7.4 \pm 0.1$ & $4.9 \pm 0.6 \mathrm{c}$ & $2.7 \pm 0.5 \mathrm{e}$ & $10.1 \pm 0.5 \mathrm{j}$ & $15.0 \pm 0.5 \mathrm{n}$ & $17.3 \pm 0.5 \mathrm{q}$ \\
\hline $9-10$ & 30 & $9.4 \pm 0.1$ & $3.6 \pm 0.5 \mathrm{c}$ & $2.2 \pm 0.3 \mathrm{e}$ & $11.6 \pm 0.3 \mathrm{k}$ & $15.2 \pm 0.5 \mathrm{n}$ & $16.9 \pm 0.5 q$ \\
\hline $11-12$ & 26 & $11.5 \pm 0.1$ & $1.9 \pm 0.4 \mathrm{~d}$ & $2.7 \pm 0.3 \mathrm{e}$ & $14.2 \pm 0.41$ & $15.9 \pm 0.5 \mathrm{n}$ & $16.2 \pm 0.5 \mathrm{r}$ \\
\hline $13-14$ & 30 & $13.5 \pm 0.1$ & $1.0 \pm 0.4 \mathrm{~d}$ & $1.5 \pm 0.3 \mathrm{e}$ & $14.9 \pm 0.31$ & $15.9 \pm 0.5 \mathrm{n}$ & $16.2 \pm 0.4 \mathrm{r}$ \\
\hline $15-16$ & 31 & $15.4 \pm 0.1$ & $0.5 \pm 0.3 \mathrm{~d}$ & $1.2 \pm 0.2 \mathrm{e}$ & $16.5 \pm 0.2 \mathrm{~m}$ & $16.9 \pm 0.5 \mathrm{p}$ & $17.2 \pm 0.4 \mathrm{q}$ \\
\hline $17-18$ & 15 & $17.4 \pm 0.1$ & 0 & $0.7 \pm 0.2 \mathrm{f}$ & $18.1 \pm 0.3 \mathrm{~m}$ & $18.1 \pm 0.3 \mathrm{p}$ & $17.4 \pm 0.6 \mathrm{q}$ \\
\hline Total & 228 & 2202 & 1008 & 415 & 2617 & 3625 & $9 \pm 0.2)$ \\
\hline \multicolumn{7}{|c|}{ No. of ova in spontaneous ovulation of virgin rats } & $15.5 \pm 0.3$ \\
\hline
\end{tabular}

Pre-implantation loss : No. of corpora lutea of pregnancy - No. of implantation sites.

Post-implantation loss: No. of implantation sites - litter size.

* All data mean $\pm \mathrm{SE}$.

Duncan's new multiple-range test : $P<0.01$ a vs $b, c$ and $d, b$ vs $c$ and $d$, c vs, $d$, e vs $f$, $g$ vs $h, i, j, k, i$ and $m, h$ vs $i, j, k, l$ and $m, i$ vs $j, k, l$ and $m, j$ vs $k, l$ and $m, k$ vs 1 and $m, l$ vs $\mathrm{m}, \mathrm{n}$ vs $\mathrm{p}, \mathrm{q}$ vs $\mathrm{r}$.

Table 2. Post-partum body and organ weight of primiparous SPF Wistar-Imamichi rats

\begin{tabular}{cccll}
\hline $\begin{array}{c}\text { Class of } \\
\text { litter size }\end{array}$ & $\begin{array}{c}\text { No. of } \\
\text { dams }\end{array}$ & $\begin{array}{c}\text { Body weight } \\
(\mathrm{g})\end{array}$ & $\begin{array}{l}\text { Ovarian } \\
\text { weight }(\mathrm{mg})\end{array}$ & $\begin{array}{l}\text { Uterine } \\
\text { weight }(\mathrm{mg})\end{array}$ \\
\hline $1-2$ & 13 & $325.0 \pm 9.2^{*}$ & $118.2 \pm 2.8 \mathrm{~b} * *$ & $1131.2 \pm 79.2 \mathrm{c}$ \\
$3-4$ & 25 & $325.4 \pm 6.7$ & $129.9 \pm 2.7 \mathrm{a}$ & $1365.1 \pm 41.8 \mathrm{~b}$ \\
$5-6$ & 28 & $327.8 \pm 6.9$ & $133.0 \pm 2.4 \mathrm{a}$ & $1629.3 \pm 55.0 \mathrm{e}$ \\
$7-8$ & 30 & $321.6 \pm 7.3$ & $127.8 \pm 2.3 \mathrm{a}$ & $1880.9 \pm 46.0 \mathrm{f}$ \\
$9-10$ & 30 & $312.3 \pm 5.9$ & $124.9 \pm 2.6 \mathrm{a}$ & $1947.4 \pm 41.8 \mathrm{f}$ \\
$11-12$ & 26 & $309.3 \pm 6.6$ & $126.8 \pm 2.7 \mathrm{a}$ & $2174.0 \pm 67.2 \mathrm{~g}$ \\
$13-14$ & 30 & $298.9 \pm 5.9$ & $121.8 \pm 3.0 \mathrm{~b}$ & $2235.6 \pm 54.1 \mathrm{~h}$ \\
$15-16$ & 31 & $319.4 \pm 5.1$ & $128.2 \pm 2.0 \mathrm{a}$ & $2359.0 \pm 64.0 \mathrm{~h}$ \\
$17-18$ & 15 & $325.4 \pm 6.8$ & $127.0 \pm 4.9 \mathrm{a}$ & $2592.8 \pm 56.2 \mathrm{i}$ \\
\hline
\end{tabular}

$*$ Mean \pm SE.

** Duncan's new multiple-range test : $\mathrm{P}<0.01$ a vs $\mathrm{b}, \mathrm{c}$ vs $\mathrm{d}$, e, f, $\mathrm{g}, \mathrm{h}$, and i.

2.2\%）が次いで低い值を示し，7〜8 匹群までは $5 \%$ にも満ない値であった。

SPF ラットにおけるこれらの成績を conv. ラットの 成績と比較すると, 産仔数の分布巾には大差ないが, 平 均産仔数は conv. ラットの11.0 0.04 匹に比べ1.4匹多 い値を示した $(P<0.001)$ 。そして 1 腹の産仔数の多少
により設けられた階級值における度数分布の最高值も conv. ラットでは11〜12匹であったのに比べ SPF ラッ トでは1階級増加して13〜14匹であった。

2 ) 初産の SPF ラットの解剖成績: 産仔数と着床数お よび排卵数の関係を調べる為に，1腹の産仔数により分 類した各階級群のラットを分娭日の翌日にそれぞれ解剖 


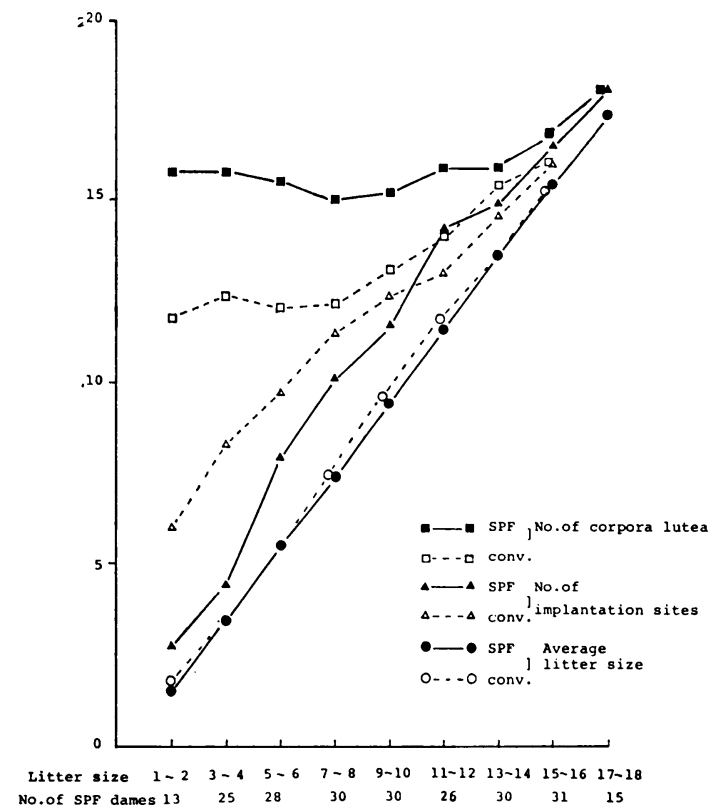

Fig. 2. Number of litter size, implantation sites and corpora lutea of pregnancy in primiparous SPF and conventional WistarImamichi rats.

し観察した結果を Table 1，2 扰よび Fig. 2 に示す。 な打 Fig. 2 に示す破線は既報の conv. ラットの成 樍 [10] である。

産仔数と着床痕数, 妊娠黄体数の関係: SPF ラット に㧊いて，産仔数 $1 \sim 2$ 匹群では 13 腹の平均産仔数は 1.5 匹であり, 着床痕数, 妊娠黄体数, 後分婏排卵数の 平均はそれぞれ $2.7 \pm 0.5$ 個， $15.8 \pm 0.9$ 個，17.8 00.9 個 であった。着床痕数は Fig. 2 に示したように産仔数の 增加とほぼ平行して增加し産仔数の少ない母体では着床 数も少ない事を示している。

交配時の排卯数の指標である妊娠黄体数は, 産仔数 1

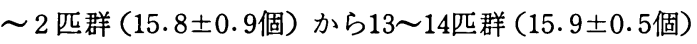
まではほぼ一定值を示したが，産仔数17〜18匹群（18.1 \pm 0.3 個）では 14 匹以下の群に比較して有意に増加した $(\mathrm{P}<0.01) 。 こ の \mathrm{SPF}$ ラットにおける妊娠黄体数は conv. ラットの戌績に比較し有意に多かった（二元配置 の分散分析法により検定 $\mathrm{P}<0.01$ )。

SPF ラットにおける受精卵の着床前および胚・胎仔 の着床後の損失 : SPF ラットにおいて，低産仔数 1〜 2 匹群では着床前の損失（妊娠黄体数一着床痕数）は $13.2 \pm 1.0$ 個と多く, 着床後の損失（着床痕数一産仔数）

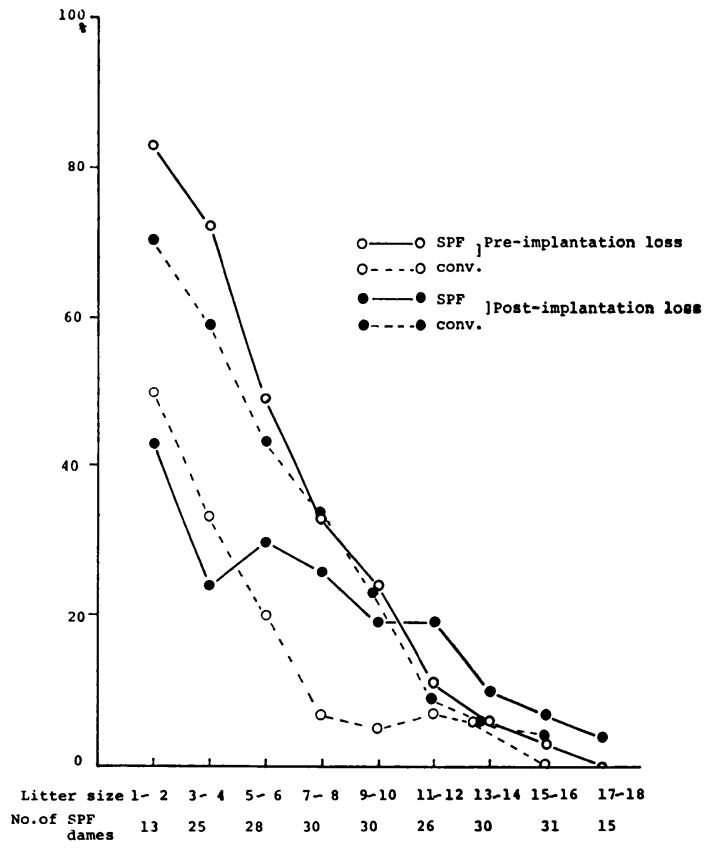

Fig. 3. Percentage of pre- and post-implantation loss of fertilized ova, embryos and fetuses in primiparous SPF and conventional Wistar-Imamichi rats.

は1.2 0.4 個と少ない値を示した。着床前損失は産仔数 の増加と共に著しく減少して 9 10匹群では3.6 0.5 個 となり, 高産仔数 17〜18 匹群では全く認められなかっ た。これに対し着床後損失は産仔数 5 〜 6 匹群から11〜 12匹群まで2.2個〜2.7個とほぼ一定值を示したが，4 4 匹 以下の低産仔数群と13匹以上の高産仔数群がそれよりや や低く約 1 個の值を示した (Table 1)。

以上の SPF ラットにおける成績を conv. ラットの成 績 [10）と比較する為, 両者の各産仔数群での着床前 の損失率 [(妊娠黄体数一着床痕数/妊娠黄体数) $\times 100]$ お上び着床後の損失率〔(着床痕数一産仔数／着床痕数） $\times 100$ ]を求めた。これらを Fig. 3 に示す。破線は conv. ラットの成績である。SPF および conv. ラットの着床 前後の損失率は低産仔数群で逆の関係を示した。すなわ ち, 低産仔数群に打ける損失率は, SPF ラットで着床 前の損失率が高值を示したのに対し, conv. ラットでは 着床後の損失率が高值を示した。この両者の関係は級中 值の 9〜10匹群まで継続した。

性腺系臓器の重量：Table 2 に示されるように卵巣 重量は, 産仔数の多臭との関連は認められなかった。子 宮重量は産仔数の増加と共に著しく重くなり低産仔数 1 
Table. 3. Examination of pathogen in SPF and conventional $\mathrm{W}$ istar-Imamichi rats

\begin{tabular}{l|c|c}
\hline \multicolumn{1}{c|}{ Species of pathogen } & SPF rat & conv. rat \\
\hline Pseudomonas aeruginosa & $0 / 20$ & - \\
Salmonella spp. & $0 / 20$ & - \\
Escherichia coli 0115 a, & & - \\
c : $\mathrm{k}$ (b) & $0 / 20$ & - \\
Pasteurella pneumotropica & $0 / 20$ & - \\
Bordetella bronchiseptica & $0 / 20$ & $10 / 19$ \\
Corynebacterium kutscheri & $0 / 20$ & $0 / 19$ \\
Tyzzer's organisms (rat) & $0 / 20$ & $3 / 19$ \\
Tyzzer's organisms (mouse) & $0 / 20$ & $0 / 19$ \\
Mycoplasma ssp & $0 / 20$ & $11 / 19$ \\
Sendai virus (HVJ) & $0 / 20$ & $0 / 19$ \\
Mouse hepatitis virus & $0 / 20$ & $4 / 19$ \\
Mouse adeno virus & $0 / 20$ & - \\
Reo virus type 3 & $0 / 20$ & - \\
Pinworm & $0 / 20$ & - \\
Tapeworm & $0 / 20$ & - \\
Giardia muris & $0 / 20$ & - \\
\hline
\end{tabular}

～ 2 匹群で $1131.2 \pm 79.2 \mathrm{mg}$, 高産仔数 17 ～18匹群で 2592.8 $556.2 \mathrm{mg}$ であった。

3）処女動物の解剖成樍: Table 1 に示されるように 自然排卵数は $15.5 \pm 0.3$ 個（35腹）であり，SPF 初産ラ ットの 交配時の 排卵数を代表した妊娠黄体数との 間に conv. ラットにおける既報 [10］と同梯有意な差はなか った。しかし SPF 処女ラットにおける 排卵数は 既報 [10] の conv. 処女ラットに扑ける13.5 0 0.1個（34腹） に比較して有意に多かった $(\mathrm{P}<0.001)$ 。

4 ) 病原体検査成績: Table 3 に示されるように SPF ラットでは16種の病原体は総べて陰性であった。なお既 報で述べたconv. ラットの成績では 7 種の病原体検査で 4 種の病原体が陽性であった。

\section{考察}

$\mathrm{SPF}$ 初産ラットの平均産仔数は12.4匹となり，既報 の conv. ラットの11.0匹に比べ多くなった $(\mathrm{P}<0.001) 。$ そして，産仔数 10 匹 以下を 分婏した母動物の 割合は conv. ラットの $38 \%$ に比べて SPF ラットでは $21 \%$ と低 率になった。このように SPF ラットに执いて平均産仔 数が増加した要因としては一般環境条件の向上, 病原体 の排除による母体・胎仔の健康增進や遺伝的素質の片寄 り等が考えられる。遺伝的片寄りについては SPF 化
（ビニールアイソレーター内で妊娠した種動物を分娩直 前に帝王切開により胎仔を取り出し，予め準備した哺乳 中の無菌動物に里仔する方式を取る）の時に面倒な作業 工程を経るため少ない種親で出発するので，この時産仔 数の多いものが片寄った可能性も考えられるかも知れな い。しかし，この点については帝王切開による里仔方式 手技で産仔数の多い腹の胎仔よりはむしろ産仔数の少な い腹の胎仔の方が里仔に成功する率が高いことを経験し ている（その理由として胎仔の大きさや活力が帝王切開 の成功の鍵となるためで, 胎仔数の多いものよりは少な い方が胎仔の大きさや活力が勝っているからである）の で種親に産仔数の多い個体が片寄った可能性は少ない。 また，著者ら [2]がこれまで一貫した種親の選抜基準で Wistar-Imamichi Rat の繁殖を最近 5 年間にわたっ て続けた経験では産仔数の 変化はほとんど 見られず, conv. 条件下に打けるラットとしては多い産仔数 (11.0 土0.04) であり，この様な産仔数の多い系統を更に多い 方向に変化させる事はきわめて難かしい。著者らの SP $\mathrm{F}$, conv, 両ラットの種親選抜基準は病原体統御掞よび 一般環境条件を除く, 䬣, 産仔数, 哺育数, 交配方式, 健康状態，性質などは同一であった。これらのことより 今後詳細な検討の必要はあるにせよ本研究において遺伝 的片寄りにより産仔数が增加したとは考えにくい。

病原体の排除による産仔数の增加の可能性については 経験的に SPF 化により増加したと思っている人は多い が直接説明できる報告は少なく, マウスなどの繁殖コロ ニーに打いて HVJ の感染により生産効率あるいは離乳 率などの一時低下があった（藤原）などの報告 $[4]$ に止 まる場合が多い。この様な傾向の中で曲淵等 $[6]$ はマ1 コプラズマの常在しているマウスの飼育室を衛生的に管 理し, マイコプラズマを排除する事により産仔数が増加 した注目すべき報告をしている。また桑水・田村 [5], Naot [8] 等は妊娠ラットにマイコプラズマを静脈注射 により感染させると流産, 胎仔死亡が生ずることを報告 している。著者らの conv. ラットもマイコプラズマに污 染していた事に着目し, 予備実験として SPF WistarImamichi Rat にマイコプラズマを経鼻感染させ，胎 仔扣よび産仔数への影響を調べた。その結果, 感染実験 群の産仔数が若干減少する傾向のある事を経験した。こ の事に関しては今後検討を重ねて行く予定であるが， 、 イコプラズマや他の病原体の侵蛽により産仔数が影響を 受ける可能性は十分に考元られる。特に低産仔数個体で の着床後損失が SPF ラットに比べ conv. ラットではき わめて多かった事について病原体の影響を考えている。 
次に，着床前の損失（排卵数一着床数）については, 実際には排卵数から受精卵数と受精卵数から着床数まで の 2 段階にわたって生じている損失を一括しているが SPF, conv, 両ラットとも低産仔数群においてかなり発 生している。両者を比較すると SPF ラットの方が多く なっている。この原因は SPF ラットの排卯数の増加も 影響していると思われるが，それにも增して着床数その ものの減少によると考えた方が適切であろう。

Falconer [3] はマウスにおいて近親交配を繰返すこ とにより，近交係数の高まりと共に着床前の損失が増加 することを報告している。一方 Mclaren [7] はマウス のミュータント系（遺伝子突然変異）の中で初期肧の死 亡が認められる各種の系統について遺伝的影響, すなわ ち致死遺伝子に関する報告をしている。この致死遺伝子 については古くは1900年代の初期に発見された，有名な 黄色致死遺伝子小モ型胚がある。また，近年特殊な 1 例 として Wakasugi [13] は近交系の DDK 䊒マウスに 他の系統の雄マウスを交雑させると初期胚の損失が増加 する事を発見し，その原因は遺伝子の不適合によると報 告している。これらの報告はすべて着床前の損失に遺伝 的な要素が関与していることを意味している。著者らの コロニーは前述したごとくクローズドコロニーによって 維持し，交配に際しては遺伝的片寄りをさけるため，兄 妹交配にならない様に注意深く交配しているので遺伝的 片寄（致死遺伝子）によって初期胚の死亡が多数発現し たとは考えにくい。また，仮に致死遺伝子の様なものが 存在したとしても，今回の Fig. 3 に示す着床前の損失 のすべてに影響するのか, あるいは低産仔数 $1 \sim 2,3$ 〜 4 匹群に特別片寄って発現するのか, これらを適切に 説明することは困難である。

次に考えられることとしては交尾によって得られる受 精卵の数の問題である。今回の研究では受精卵を観察し ていないが，著者らはラットの交配に際し排卵された卵 子すべてが受精するか否かについて交配時刻別（発情前 期の日午前 11 時から発情期の日午前 11 時までの間）に検 討した結果，交尾が発情終了まぎわに成立すると受精卵 数の極めて減少することを確認している。この成績を直 接あてはめることはできないが，著者らのコロニ一の交 配方式（雄 1 対倠 5，2 週間同居）において同一日に発 情倠が複数になる場合に，一匹の雄が順次複数の雌に交 尾することになるので，あるいは交尾が発情終了まぎわ に成立することで受精卵数の減少（卵子および精子の寿 命による）を来たすかも知れない。この点については今 後さらに検討を進める必要がある。
後 1 つの問題としては SPF における排卯数と conv. における排卵数では SPF における排卵数の方が多くな っている点である。現在の所, 病原微生物の感染により 排卵数が少なくなると云う報告はないので遺伝的あるい は環境的に検討を加えて行く必要がある。ただ脳のホル モン分泌に関係ある中枢を抑制する病原微生物が存在し たり，あるいは健康状態の向上がホルモン分泌増加に結 び付くとすれば，それらの問題についても解明する必要 がある。

以上の如く病原体の污染を防止した SPF ラットにお いては conv. ラットに比べて産仔数の増加が認められ， その原因は排卯数そのものの増加と低産仔数群におけ る着床後の胚・胎仔の損失の減少によることが明になっ た。さらに低産仔数群における着床前の損失は SPF 群 の方が多くなっていた事など興味深い。

\section{要 約}

病原微生物や寄生虫の侵入を可能な限り防御した厳重 な隔離方式施設 (Barrier System) の飼育条件下で 3 ケ月齢の初産 SPF Wistar-Imamichi Rat 6,142 腹 を用い産仔数と着床痕数, 妊娠黄体数を観察, 記録し た。この成績を既報 [10] のコンベンショナル条件下で 得たものと比較し, Barrier System が受精卵の着床 前の損失および着床後の肧・胎仔の損失率に及ぼす効果 について検討した。その結果 1) SPF ラットの産仔数 は 6,142 腹の平均が $12.4 \pm 0.04$ 匹であり, 最少 1 より最 大20匹にわたって分布した。又 SPF ラットとコンベン ショナルラットの成績を比較すると平均産仔数において

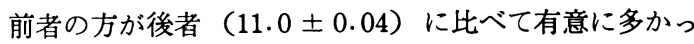
た $(\mathrm{P}<0.001) 。 2)$ 妊娠黄体数は各産仔数間でほとん ど差異が見られなかったが，コンベンショナルラットと の比較ではSPF ラットの方が多かった。3）着床後の 損失（着床痕数一産仔数）は産仔数 $5 \sim 6$ 匹群から11〜 12匹群まで2.2〜2.7個と一定した低い值を示し, さらに 低産仔数群と高産仔数群がそれより少なく約 1 個の值を 示した。又コンベンショナルラットに比べて10匹以下の 産仔数群で著しく減少した。

以上の成績から, 病原体の污染防止および一般環境の 統御下に育成された SPF ラットにおいては，産仔数の 増加が認められ，その主要因は排卯数そのものの増加と 着床後の胚・胎仔の損失の減少によることが明になっ た。 
稿を終わるに当り，本研究に御協力いただきました国立䂆防 衛生研究所の斎藤学博士に深く感謝致します。また本研究の御 指導を賜った東北大学医学部の信永利馬助教授に深甚の謝意を 表します。

\section{文献}

[1] 今道友則(1961). 繁殖生理学および内分泌学研究に適する 生理的特徴を目標とした Wistar-Imamichi rat の育成に ついて, 日本臨床, 19，99-109.

［2］今道友則 - 本田紀代子 (1965). Wistar-Imamichi Rat の 産仔数向上に関する改良成果について，日本畜産学会誌， 36 (別号), 46.

[3] Falconer, D, S, (1960). The genetics of litter size in mice. J, Cell, Physiol. 1. Suppl., 56, 153-167.

[4] 藤原公策 (1981). 微生物病コントロール, 癌と化学療法, 8 (10), 1649-1659.

［5］桑水都郎・田村弘・田嶋嘉男・前島一淑・石原智明・今道 友則 (1977). ラットにおける Mycoplasuma の胎仔感染 について，日本実験動物研究会，第12回発表会講演要旨, p. 22 .

［6］曲淵輝夫・福田妙子・興水䔩(1982). 繁殖用マウスの衛生 的飼育管理の改善による呼吸器病撲滅の試み。Exp. An. im., 31 (3), 159-164.
[7] McLaren, A. (1976). Genetics of the early mouse embryo. Ann. Rev. Genet., 10, 361-388.

[8] Naot, Y., Sharf, M., and Klein, A. (1977). Mycoplasma infection in plegnant Rats : Low viability of foetuses and new born offspring. J. Med, Microbiol, 11, 261-267.

［9］西田周作 (1974)，量的形質の遺伝．畜産技術論．pp，281 -289 , 社団法人 農山漁村文化協会, 東京.

[10］若藤靖匡・今道友則(1982). 多産系ラットの初産次に少数 発現する低 Iitter Size 出産母体に認められた受精卵の着 床前 loss および着床後の胚・胎仔の loss について. 家 畜繁殖誌. 28(1), 36-41

［11］若藤靖匡 - 外尾亮治・高橋和明 (1982). 初産次に産仔数の 少なかったウィスター・今道ラットの 2 産次における排卵 数・着床数㧍よび産仔数について，家畜繁殖誌. 28 (3), 145-149.

[12］若藤靖匡 - 天尾弘実 - 外尾亮治 - 筏井洋 - 重盛正彦 - 今道 友則 (1977). 飼育環境の微生物污染防止が Wistar-Imamichi rat の産仔数に及ぼす影響. 家畜繁殖誌. 23 (5), 66.

[13] Wakasugi, N. (1973). Studies on fertility of DDK mice : Reciprocal crosses between DDK and $\mathrm{C} 57 \mathrm{BL} /$ $6 \mathrm{~J}$ strain and experimental transplantation of ovary. J, Reprod, Fert, 33, 283-291. 